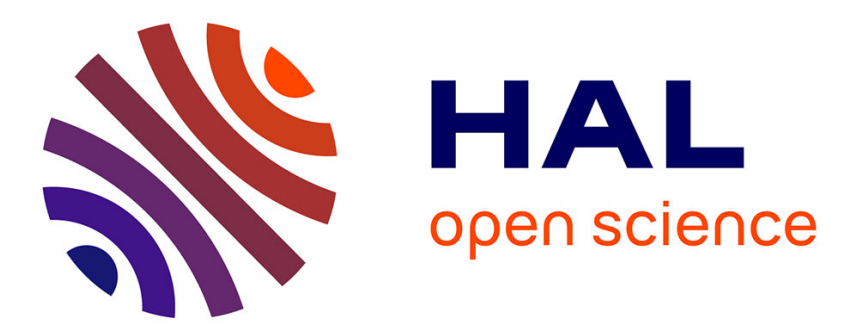

\title{
Bis(imino)carbazolate lead(II) fluoride and related halides
}

Peter M Chapple, Ghanem Hamdoun, Thierry Roisnel, Jean-François Carpentier, Hassan Oulyadi, Yann Sarazin

\section{- To cite this version:}

Peter M Chapple, Ghanem Hamdoun, Thierry Roisnel, Jean-François Carpentier, Hassan Oulyadi, et al. Bis(imino)carbazolate lead(II) fluoride and related halides. Dalton Transactions, 2021, 50 (26), pp.9021-9025. 10.1039/d1dt01615f . hal-03282745

\section{HAL Id: hal-03282745 \\ https://hal.science/hal-03282745}

Submitted on 15 Sep 2021

HAL is a multi-disciplinary open access archive for the deposit and dissemination of scientific research documents, whether they are published or not. The documents may come from teaching and research institutions in France or abroad, or from public or private research centers.
L'archive ouverte pluridisciplinaire HAL, est destinée au dépôt et à la diffusion de documents scientifiques de niveau recherche, publiés ou non, émanant des établissements d'enseignement et de recherche français ou étrangers, des laboratoires publics ou privés. 


\title{
Bis(imino)carbazolate lead(II) fluoride and related halides $\dagger$
}

\author{
Peter M. Chapple, ${ }^{a}$ Ghanem Hamdoun, ${ }^{\mathrm{b}}$ Thierry Roisnel, ${ }^{\mathrm{a}}$ Jean-François Carpentier, ${ }^{\mathrm{a}}$ Hassan \\ Oulyadic and Yann Sarazin*a
}

The versatility of a bulky bis(imino)carbazolate ligand in lead(II) chemistry is illustrated by the syntheses of a soluble, heteroleptic lead(II) fluoride and of several halide ( $\mathrm{Cl}, \mathrm{Br} \mathrm{I})$, amide and hydrocarbyl congeners. All complexes have been structurally authenticated, and a full set of ${ }^{207} \mathrm{~Pb}$ NMR data is discussed.

Since the seminal report of a stable $\sigma$-bonded organolead(II) complex, $\left[\mathrm{Pb}\left\{\mathrm{CH}\left(\mathrm{SiMe}_{3}\right)_{2}\right\}_{2}\right],{ }^{1}$ low-valent lead(II) compounds have been attracting some attention, although on the whole they remain less developed that their lighter Ge(II) and Sn(II) analogues. The introduction of bulky ligands to the field has enabled the syntheses of hitherto elusive species. The molecular $\mathrm{Pb}(\mathrm{II})-$ fluoride $\left[\left\{\left.\mathrm{BD}\right|^{\mathrm{DiPP}}\right\} \mathrm{PbF}\right]$, where $\left\{\left.\mathrm{BDI}\right|^{\mathrm{DiPP}}\right\}^{-}$is the versatile $\beta$-diketiminate $\mathrm{CH}\left[\mathrm{C}(\mathrm{Me}) \mathrm{N}-2,6-{ }^{-} \mathrm{Pr}_{2}-\mathrm{C}_{6} \mathrm{H}_{3}\right]_{2}{ }^{-}$, was reported in $2011 .^{2}$ It is only in 2017 that the first $\mathrm{Pb}$ (II)-hydride, the dimeric $\left[\left\{2,6-\mathrm{Trip}_{2}-\mathrm{C}_{3} \mathrm{H}_{3}\right\} \mathrm{Pb}(\mu-\mathrm{H})\right]_{2}$ (Trip = 2,4,6-i $\mathrm{Pr}_{3}-\mathrm{C}_{6} \mathrm{H}_{2}$ ), was described. ${ }^{3}\left[\left\{\mathrm{Carb}^{\text {tbp }}\right\} \mathrm{Pb}\right]^{+} .\left[\mathrm{Al}\left(\mathrm{OC}_{4} \mathrm{~F}_{9}\right)_{4}\right]^{-}$, featuring a onecoordinate $\mathrm{Pb}$ (II) cation encapsulated in the 1,8-bis(3,5-di-tertbutylphenyl)-3,6-di-tert-butyl-carbazolate ligand (aka $\left\{\text { Carb }^{\text {tbp }}\right\}^{-}$ ) having bulky flanking aromatic groups, was obtained in $2019 .{ }^{4}$ Although $\mathrm{Pb}(\mathrm{II})$ complexes supported with amidinate and guanidinate ${ }^{5}$ ligands exist, the $\beta$-diketiminato ligand $\left\{B D I^{D i p p}\right\}^{-}$is arguably the most commonly used chelating amide ligand in this area due to its simple synthesis, useful NMR resonances and relative kinetic and thermodynamic stability arising from its delocalised charge and from the chelate effect. It has been used to support a range of heteroleptic $\mathrm{Pb}$ (II) complexes, e.g. amides, $^{6}$ alkyls, ${ }^{7}$ triflates, ${ }^{7 a}$ halides, ${ }^{2,6 a}$ phosphides, ${ }^{6 b, 8}$ chalcogenides ${ }^{9}$ and alkoxides. ${ }^{10}$

Developing new stable soluble sources of $\mathrm{Pb}(\mathrm{II})$ is potentially of interest to assist in not only expanding the range of uses for

\footnotetext{
a. Univ Rennes, CNRS, ISCR (Institut des Sciences Chimiques de Rennes) - UMR 6226, Rennes F-35000, France.

E-mail: yann.sarazin@univ-rennes1.fr; Tel: +33 223-233019.

b. Euromed University of Fes (UEMF), Fez, Morocco.

c. Normandie Université, UNIROUEN, INSA de Rouen, CNRS, Laboratoire COBRA (UMR 6014 \& FR 3038), 76000 Rouen (France)

Electronic Supplementary Information (ESI) available: Synthetic and analytical details for all compounds; X-ray data (incl. CIF files) for CCDC 2080122-2080128. See DOI: $10.1039 / x 0 x \times 00000 x$
}

$\mathrm{Pb}$ (II) materials, but also to gain further understanding about the fundamental organometallic chemistry and bonding with lead. In this regard, ${ }^{207} \mathrm{~Pb}$ NMR spectroscopy is a useful tool in order to gain information about the chemical environment of the $\mathrm{Pb}$ (II) atom. ${ }^{207} \mathrm{~Pb}$ NMR has many desirable characteristics; ${ }^{207} \mathrm{~Pb}$ is a reasonably abundant isotope $(22.6 \%)$, and has a $1 / 2 \mathrm{spin}$ and good NMR receptivity $\left(11.9\right.$ vs $\left.{ }^{13} \mathrm{C}\right)$. Despite this, ${ }^{207} \mathrm{~Pb} \mathrm{NMR}$ data are often not recorded for organometallic complexes, usually due to problems with chemical shift anisotropy. For instance, the set of halide complexes $\left[\left\{B D \mid{ }^{D i P P}\right\} P b X\right]$ is available for $\mathrm{X}=\mathrm{F}, \mathrm{Cl}, \mathrm{Br}$ and I, 2,6a but the ${ }^{207} \mathrm{~Pb}$ NMR chemical shift has only been reported for the fluoride ${ }^{2}$ and the chloride ${ }^{11}\left(\delta_{207 p b}\right.$ 787 and 1413 ppm, respectively).

In this context, we are reporting here on a complete series of easily prepared and soluble lead(II) halides supported by a bulky bis(imino)carbazolate, and on their full set of high resolution ${ }^{207} \mathrm{~Pb}$ NMR and crystallographic data. It is also shown how they can be used as convenient precursors to access organolead(II) derivatives.

We have shown that the bis(imino)carbazolate $\left\{\right.$ Carb $^{\text {DipP }}$ ligand (DiPP $=2,6-\mathrm{Pr}_{2}-\mathrm{C}_{6} \mathrm{H}_{3}$ ) effectively stabilises heteroleptic complexes of the large alkaline-earth metals. ${ }^{12}$ The equimolar reaction in thf of [ $\left\{\mathrm{Carb}^{\text {DiPP }}\right\} \mathrm{K} \cdot($ thf $\left.)\right]$ with $\mathrm{Pbl}_{2}$ and $\mathrm{PbBr}_{2}$ yielded the corresponding heteroleptic, non-solvated [\{Carb $\left.\left.{ }^{\mathrm{DiPP}}\right\} \mathrm{PbX}\right]$ in good yields ( $\mathrm{X}=\mathrm{I}, \mathbf{1}, 75 \%$; $\mathrm{Br}, \mathbf{2}, 79 \%$; Scheme 1). The chloride $\left[\left\{C a_{b}{ }^{\text {DiPP }}\right\} \mathrm{PbCl}\right]$ (3) was obtained in $82 \%$ yield upon stoichiometric reaction in thf of the lithium precursor [\{Carb $\left.{ }^{\text {DiPP }}\right\}$ Li.(thf $\left.)_{2}\right]$ and $\mathrm{PbCl}_{2}$. The complexes were isolated as bright yellow powders that are very soluble in aromatic solvents and ethers. However, salt metathesis reactions with $\mathrm{PbF}_{2}$ failed to deliver the sought $\mathrm{Pb}$ (II)-fluoride derivative, likely due to the

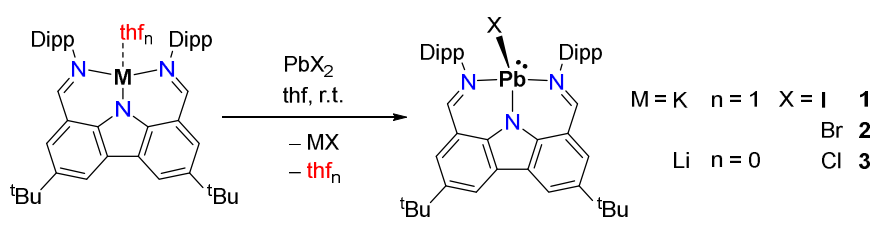

Scheme 1 Syntheses of $\left[\left\{C a r b{ }^{D i P P}\right\} P b X\right](X=I, 1 ; B r, 2 ; C l, 3)$. DiPP $=2,6-\mathrm{Pr}_{2}-\mathrm{C}_{6} \mathrm{H}_{3}$. 


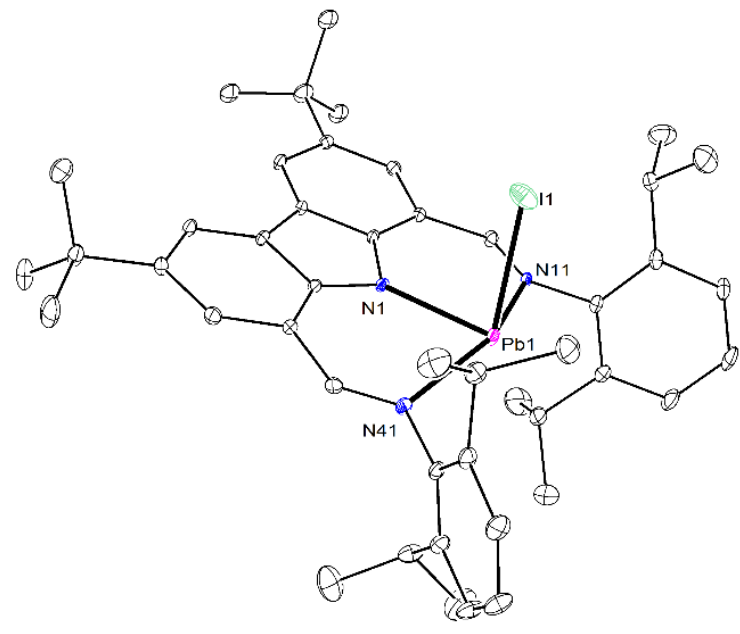

Fig. 1 ORTEP view of the molecular solid-state structure of [\{Carb $\left.{ }^{\text {DipP }}\right\}$ PbI] (1). Ellipsoids at the $30 \%$ probability level. All $\mathrm{H}$ atoms omitted for clarity. Selected bond lengths $(\AA ̊)$ : Pb1-I1 = 2.9441(5), Pb1-N1 = 2.294(2), Pb1-N11 = 2.532(3), Pb1 $\mathrm{N} 41=2.547(3)$. Selected angles $\left({ }^{\circ}\right):|1-\mathrm{Pb} 1-\mathrm{N} 1=88.24(7)| 1-,\mathrm{Pb} 1-\mathrm{N} 11=95.05(6)$, I1-Pb1-N41 = 98.35(6), N1-Pb1-N11 = 79.23(9), N1-Pb1-N41 = 80.72(9), N11-Pb1 $\mathrm{N} 41=155.45(9), \mathrm{N} 11-\mathrm{N} 1-\mathrm{N} 41=105.76(10)$. Distance from Pb1 to N1N11N41plane: $0.379(2)$ Á.

relative insolubility of $\mathrm{PbF}_{2}$ in thf or due to the relatively high crystal lattice energy of $\mathrm{PbF}_{2}$ (estimated by the Kapustinskii ${ }^{13}$ and Born-Mayer ${ }^{14}$ equations to be $-2495 \mathrm{~kJ} \mathrm{~mol}^{-1}$ and $-2392 \mathrm{~kJ}$ mol $^{-1}$, respectively). ${ }^{15}$

The identity and purity of 1-3 was established on the basis of X-ray diffraction crystallography and NMR spectroscopic data recorded in benzene- $d_{6}$. Their ${ }^{1} \mathrm{H}$ NMR spectra all display the same multiplicity patterns. The $\mathrm{CH}$ imine resonance $\left(\delta_{\mathrm{H}}: 1,8.37\right.$ ppm; 2, 8.44 ppm; 3, $8.45 \mathrm{ppm}$ ) is increasingly shielded with halogen size. The isopropyl groups in the DiPP substituents are non-equivalent at room temperature, resulting in two $\mathrm{CH}$ heptets $\left(\mathbf{1}, \delta_{\mathrm{H}} 3.88\right.$ and $3.07 \mathrm{ppm} ; \mathbf{2}, 3.84$ and $3.03 \mathrm{ppm} ; \mathbf{3}, 3.79$ and $3.01 \mathrm{ppm})$. The ${ }^{207} \mathrm{~Pb}$ NMR spectra each display a welldefined singlet $\left[\delta_{\mathrm{Pb}}(\mathrm{ppm})\right.$ and $\Delta \mathrm{v}_{1 / 2}(\mathrm{~Hz}): 1,1542 / 239 ; 2$, 1054/186; 3, 791/190], with increased shielding correlating with decreasing halogen size. ${ }^{207} \mathrm{~Pb} \mathrm{NMR}$ has a range of ca. $17000 \mathrm{ppm}$, from + 11000 to $-6000 \mathrm{ppm}$, with the most deshielded signals generally being from alkyl plumbylenes, while the most shielded are attributed to plumbocenes. ${ }^{16}$ There is a typically strong relation between coordination number and $\delta_{\mathrm{Pb}}$, with higher coordination numbers resulting in lower chemical shifts. The ${ }^{207} \mathrm{~Pb}$ NMR chemical shift for $\mathbf{3}$ is noticeably upfield shifted from other known heteroleptic $\mathrm{Pb}$ (II) chlorides supported by monoanionic N-type ligands, e.g. the threecoordinate $\left[\left\{B D I^{D i P P}\right\} P b C l\right](1413 \mathrm{ppm})^{11}$ and $\left[\left\{\mathrm{N}^{\wedge} \mathrm{N}^{\mathrm{DiPP}}\right\} \mathrm{PbCl}\right.$ (1317 ppm, where $\left\{\mathrm{N}^{\wedge} \mathrm{N}^{\mathrm{DiPP}}\right\}^{-}$is a iminoanilide bearing a DiPP group), ${ }^{17}$ or also the two-coordinate [\{Carb $\left.\left.{ }^{\text {tbp }}\right\} \mathrm{PbCl}\right]$ (2398 $\mathrm{ppm}) .{ }^{4}$ Moreover, the ${ }^{207} \mathrm{~Pb}$ resonance for the $\mathrm{Pb}(\mathrm{II})$ bromide 2 is also shifted highfield compared to the three-coordinate $\left[\mathrm{Pb}\left\{\mu-\mathrm{SAr}{ }^{\mathrm{Me} 6}\right\} \mathrm{Br}\right]_{2}\left(\delta_{\mathrm{Pb}} 4283 \mathrm{ppm} ; \mathrm{SAr}^{\mathrm{Me} 6}=\mathrm{C}_{6} \mathrm{H}_{3}-2,6-\left(\mathrm{C}_{6} \mathrm{H}_{2}-2,4,6-\right.\right.$ $\left.\mathrm{Me}_{3}\right)_{2}$ ). These observations suggested that 1-3 form fourcoordinate complexes. We did not find in the literature any comparative ${ }^{207} \mathrm{~Pb}$ NMR data for $\mathrm{Pb}(\mathrm{II})$ iodides relevant to 1 . For instance, $\left[\left\{\left.\mathrm{BDI}\right|^{\mathrm{DiPP}}\right\} \mathrm{Pbl}\right]^{3 \mathrm{a}}$ and $\left[\left\{\mathrm{CH}\left[\mathrm{C}(\mathrm{Me}) \mathrm{N}-4-{ }^{\mathrm{i}} \mathrm{Pr}-\mathrm{C}_{6} \mathrm{H}_{4}\right]_{2}\right\} \mathrm{Pbl}\right]^{18}$ have both been structurally authenticated, but their ${ }^{207} \mathrm{~Pb}$ NMR data are not available.

The XRD structures of 1-3 all reveal a single molecule in the asymmetric unit cell (plus a molecule of toluene for $\mathbf{2}$ and $\mathbf{3}$ ), with very similar four-coordinate distorted see-saw geometries around the central $\mathrm{Pb}$ atom. The structure of the iodide $\mathbf{1}$ is displayed in Fig. 1 with its relevant metric parameters (see SI for 2 and 3, Fig. S30 and S31). The Pb- $\mathrm{N}_{\text {carb }}$ interatomic distances are similar for the three compounds $(\mathbf{1}=2.294(2) \hat{A} ; \mathbf{2}=2.278(4)$ Á; $3=2.292(3) \AA ̊ A)$, while the $\mathrm{Pb}-\mathrm{X}$ bond length obviously decreases with halogen size (1 (I), 2.9441(5) Á; 2 (Br), 2.6925(7) Á; 3 (Cl), 2.5631(13) ̊̊). The $\mathrm{N}_{\text {carb }}-\mathrm{Pb}-\mathrm{X}$ angle is also similar for all three compounds, in the range $87.72(11)-88.24(7)^{\circ}$, though all are significantly distorted from the idealised equatorialequatorial see-saw geometry of $120^{\circ}$. The distance from the $\mathrm{Pb}$ atom to the plane defined by the $\mathrm{N}_{\text {carb }}$ and the two $\mathrm{N}_{\text {imine }}$ atoms (aka N1, N11 and N41) in $\mathbf{1}(0.389(2)$ Á) is slightly greater than in 2 and $3(0.244(3)$ and $0.258(3) \AA$ Á).

The heteroleptic lead(II) amide [\{ $\left.\left.\mathrm{Carb}^{\mathrm{DiPP}}\right\} \mathrm{PbN}\left(\mathrm{SiMe}_{3}\right)_{2}\right]$ (4) was isolated in a near-quantitative yield as a bright yellow powder following the protonolysis reaction between $\left\{\right.$ Carb $\left.^{\text {DiPP }}\right\} \mathrm{H}$ and $\left[\mathrm{Pb}\left\{\mathrm{N}\left(\mathrm{SiMe}_{3}\right)_{2}\right\}_{2}\right]$. The reaction required forcing conditions (refluxing toluene, $48 \mathrm{~h}$ ) to proceed effectively. Complex 4 is surprisingly poorly soluble in aliphatic hydrocarbons, but reasonably soluble in aromatic solvents such as benzene or toluene. Single crystals suitable for XRD analysis were grown from a saturated solution in toluene- $d_{8}$. The complex exists as a four-coordinate monomer (Fig. 2), with geometrical features and a see-saw arrangement around the central $\mathrm{Pb}$ atom that are reminiscent of those in 1-3. The $\mathrm{Pb}-\mathrm{N}_{\text {carb }}$ bond distance in 4 $\left(2.3427(17) \AA\right.$ ) is slightly longer than in 1-3. The two $\mathrm{Pb}-\mathrm{N}_{\text {imine }}$ distances in 4 (2.6203(18) and 2.6494(18) Å) are longer than in the halide complexes, as is the $\mathrm{N}_{\text {imine }}-\mathrm{N}_{\text {carb }}-\mathrm{N}_{\text {imine' }}$ angle $\left(108.55(7)^{\circ}\right.$, compared to $105.76(10)$ in 1 for instance) indicating a widening of the ligand pocket to accommodate the bulkier

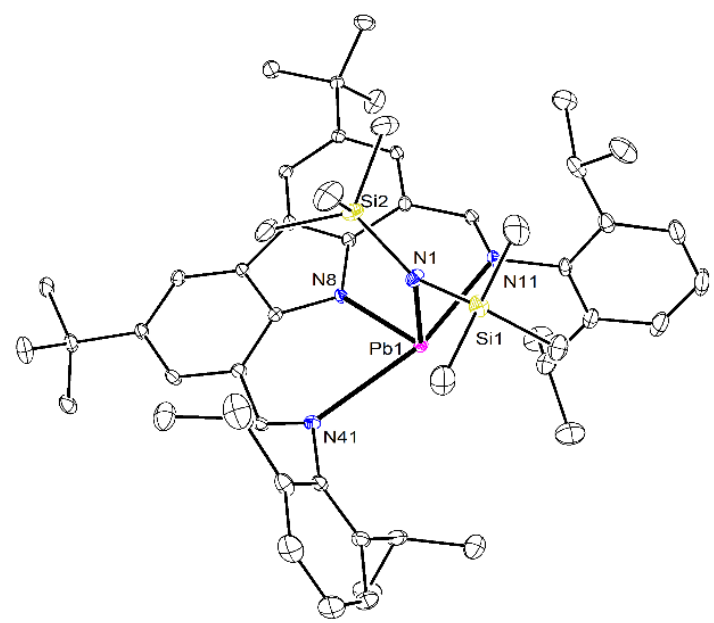

Fig. 2 ORTEP view of the molecular solid-state structure of [\{Carb $\left.\left.{ }^{\mathrm{DiPP}}\right\} \mathrm{PbN}\left(\mathrm{SiMe}_{3}\right)_{2}\right]$ (4). Ellipsoids at the $30 \%$ probability level. All $\mathrm{H}$ atoms omitted for clarity. Selected bond lengths $(\AA ̊):$ Pb1-N1 = 2.2413(19), $\mathrm{Pb} 1-\mathrm{N} 8=2.3427(17), \mathrm{Pb} 1-\mathrm{N} 11=$ 2.6203(18), Pb1-N41 = 2.6494(18). Selected angles $\left({ }^{\circ}\right): \mathrm{N} 1-\mathrm{Pb} 1-\mathrm{N} 8=102.79(7), \mathrm{N} 1-$ Pb1-N11 = 94.23(6), N1-Pb1-N41 = 95.51(6), N8-Pb1-N11 = 78.56(6), N8-Pb1-N41 $=95.51(6), \mathrm{N} 11-\mathrm{Pb} 1-\mathrm{N} 41=158.10(6), \mathrm{N} 11-\mathrm{N} 8-\mathrm{N} 41=108.55(7)$. Distance from Pb1 to N8N11N41-plane: 0.150(1) Á. 

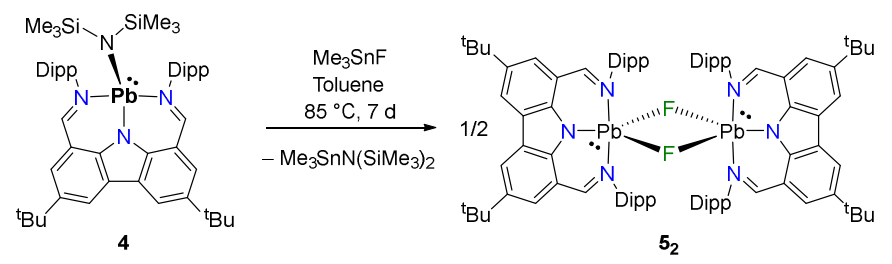

Scheme 2 Syntheses of $\left[\left\{\operatorname{Carb}^{\mathrm{DiPP}}\right\} \mathrm{Pb}(\mu-\mathrm{F})\right]_{2}\left(\mathbf{5}_{\mathbf{2}}\right)$. DiPP $=2,6^{-\mathrm{i}} \mathrm{Pr}_{2}-\mathrm{C}_{6} \mathrm{H}_{3}$.

hexamethyldisilazide ligand. The $\mathrm{Pb}-\mathrm{N}_{\text {silazide }}$ bond length in 4 $(2.2413(19) \AA)$ is half-way between those in the two-coordinate $\left[\left\{\mathrm{Carb}^{\mathrm{tbp}}\right\} \mathrm{PbN}\left(\mathrm{SiMe}_{3}\right)_{2}\right] \quad\left(2.2008(27) \AA^{19}\right)$ and the threecoordinate $\left[\left\{\mathrm{BDI}^{\mathrm{DiPP}}\right\} \mathrm{PbN}\left(\mathrm{SiMe}_{3}\right)_{2}\right]\left(2.281(3) \AA^{6 \mathrm{a}}\right)$. The ${ }^{207} \mathrm{~Pb} \mathrm{NMR}$ spectrum of 4 features a broad singlet at $\delta_{\mathrm{Pb}} 1347 \mathrm{ppm}\left(\Delta \mathrm{v}_{1 / 2}=\right.$ $517 \mathrm{~Hz}$ ), i.e. much more highfield than these two complexes $\left[\delta_{\mathrm{pb}}\right.$ $3345\left(\Delta v_{1 / 2}=450 \mathrm{~Hz}\right)$ and $1824 \mathrm{ppm}$, respectively $\left.{ }^{6 \mathrm{~b}, 19}\right]$.

The lead(II) fluoride analogue of the halide complexes 1-3 was eventually synthesised by reacting the fluorinating reagent $\mathrm{Me}_{3} \mathrm{SnF}$ with compound 4 . The reaction proceeds smoothly (though slowly, requiring 7 days to reach completion) at $85{ }^{\circ} \mathrm{C}$ to give $\left[\left\{\mathrm{Carb}^{\mathrm{DiPP}}\right\} \mathrm{PbF}\right]$, which crystallised as the unusual dimer $\left[\left\{\text { Carb }^{\text {DiPP }}\right\} \mathrm{Pb}(\mu-\mathrm{F})\right]_{2}\left(\mathbf{5}_{\mathbf{2}}\right)$ (Scheme 2). The $C_{2}$-symetric molecular solid-state structure displayed in Fig. 3 reveals a near-perfect square pyramidal arrangement $\left(\tau_{5}=0.02\right)$, with the $N_{\text {carb }}$ atom in apical position, about each of the five-coordinate $\mathrm{Pb}$ atoms. At a distance of $1.369(2) \AA$, the $\mathrm{Pb}$ atom sits very significantly out of the ligand plane defined by $N 2 N 11 N 41$, with relatively long $\mathrm{Pb}-\mathrm{N}_{\text {imine }}$ distances $(2.641(2)$ and $2.700(2) \AA$ ). This geometry is starkly different from that in the monomeric 1-3, where the $\mathrm{Pb}$ atom sits only slightly out of the NNN ligand plane (see above); this distance is also much larger than in the amide parent $4(0.2269(18) \AA)$. As expected for a bridging ligand, the $\mathrm{Pb}-\mathrm{F}$ interatomic distances in $\mathbf{5} \mathbf{2}$ (2.3042(17) and 2.3265(17) Å) are much longer than in the monomeric $\left[\left\{\left.B D\right|^{\text {DiPP }}\right\} \mathrm{PbF}\right]$ (2.088(17) Å), ${ }^{2}$ the only other know molecular lead(II)-fluoride.

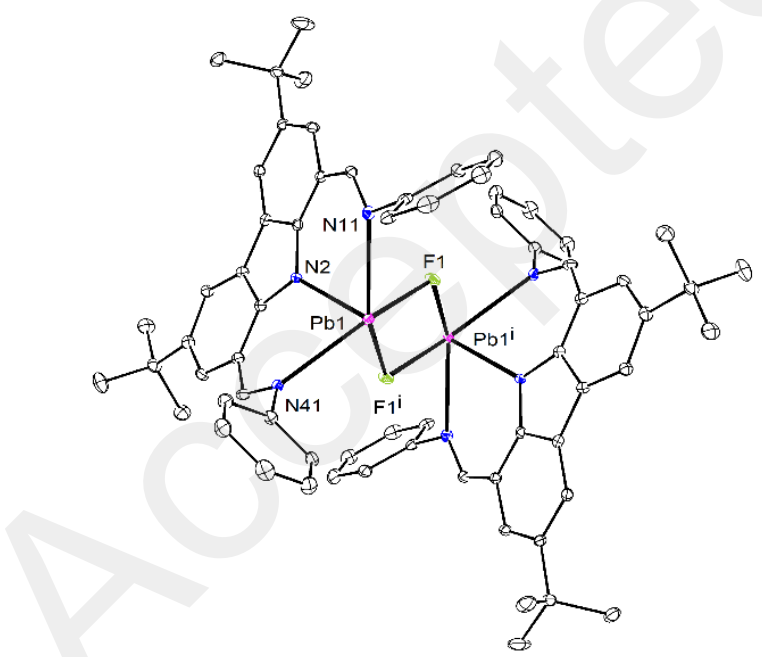

Fig. 3 ORTEP view of the molecular solid-state structure of $\left[\left\{\mathrm{Carb}^{\mathrm{DiPP}}\right\} \mathrm{Pb}(\mu-\mathrm{F})\right]_{2}\left(\mathbf{5}_{\mathbf{2}}\right)$ Ellipsoids at the $30 \%$ probability level. All $\mathrm{H}$ atoms and $\mathrm{Pr}$ groups omitted for clarity. Selected bond lengths ( $\AA$ ): Pb1-F1 = 2.3042(17), Pb1-F1 $=2.3265(17), \mathrm{Pb} 1-$ $\mathrm{N} 2=2.321(2), \mathrm{Pb} 1-\mathrm{N} 11=2.641(2), \mathrm{Pb} 1-\mathrm{N} 41=2.700(2)$. Selected angles $\left({ }^{\circ}\right)$ : F1$\mathrm{Pb} 1-\mathrm{F} 1 \mathrm{i}$ 70.67(7), F1-Pb1-N2 = 91.79(7), F1-Pb1-N11 = 78.54(7), F1- Pb1-N41 =

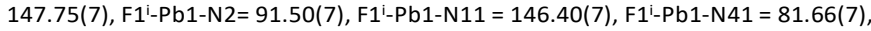
$\mathrm{N} 2-\mathrm{Pb} 1-\mathrm{N} 11=76.06(8), \mathrm{N} 2-\mathrm{Pb} 1-\mathrm{N} 41=72.25(7), \mathrm{N} 11-\mathrm{Pb} 1-\mathrm{N} 41=122.05(7), \mathrm{Pb} 1-$ $\mathrm{F} 1-\mathrm{Pb} 1^{\mathrm{i}}=109.33(7)$. Distance from Pb1 to N2N11N41-plane: $1.369(2)$ Á.
Complex $\mathbf{5}_{2}$ dissolves well in aromatic hydrocarbons and ethers; as such, it is a rare example of soluble $\mathrm{Pb}$ (II) fluoride. ${ }^{2}$ Diffusion coefficient-molecular weight analysis by DOSY NMR spectroscopy in benzene- $d_{6}$ (see $\mathrm{SI}$ ) indicated with a great level of confidence that the dimer splits in solution to generate the monomeric [ $\left.\left\{\mathrm{Carb}^{\mathrm{DipP}}\right\} \mathrm{PbF}\right](\mathbf{5})$. All other complexes $\mathbf{1 - 4}$ remain monomeric in solution. The ${ }^{19} \mathrm{~F}$ NMR spectrum of $\mathbf{5}$ exhibits a resonance at $\delta_{\mathrm{F}}-110 \mathrm{ppm}$, with clearly detectable satellites due to coupling with the $\mathrm{Pb}$ atom $\left({ }^{1} J_{\mathrm{F}-\mathrm{Pb}} \sim 3350 \mathrm{~Hz}\right)$. Accordingly, its ${ }^{207} \mathrm{~Pb}$ NMR spectrum reveals a doublet centred on $\delta_{\mathrm{Pb}} 332 \mathrm{ppm}$ with a ${ }^{1} J_{\mathrm{Pb}-\mathrm{F}}$ scalar coupling constant of $3350 \mathrm{~Hz}$. The ${ }^{207} \mathrm{~Pb}$ data is consistent with a monomeric complex and $\mathrm{Pb}(\mathrm{II})$ in a fourcoordinate environment. The resonance is deshielded compared to [ $\left.\left\{\left.\mathrm{BD}\right|^{\mathrm{DiPP}}\right\} \mathrm{PbF}\right]\left(\delta_{\mathrm{Pb}} 784 \mathrm{ppm},{ }^{1} \mathrm{Jpb}_{\mathrm{Pb}}=2792 \mathrm{~Hz}\right){ }^{2}$

The chemical shift of $\delta_{\mathrm{Pb}} 332 \mathrm{ppm}$ for 5 (halide $=F$ ) fits well with the trend for the other Pb-halides, that is, $\delta_{\mathrm{Pb}} 1542(\mathbf{1}-1)$, $1054(2-\mathrm{Br})$ and $791(3-\mathrm{Cl}) \mathrm{ppm}$. This trend, which strongly suggests that there is a clear upfield chemical shift with increasing electronegativity of the halide, is the opposite of expectations based on $\sigma$-inductive effects. Yet, it is known that the electron-donating or -withdrawing ability of the ' $\mathrm{X}$ ' reactive ligand does not dictate chemical shift in ${ }^{207} \mathrm{~Pb} N M R .{ }^{7 b}$ Instead, ${ }^{207} \mathrm{~Pb}$ NMR chemical shifts $\delta$ are heavily influenced by the different relative contributions to the isotropic shielding $(\sigma)$ of the ${ }^{207} \mathrm{~Pb}$ nucleus from diamagnetic $\left(\sigma^{\mathrm{D}}\right)$, paramagnetic $\left(\sigma^{\mathrm{P}}\right)$ and spin-orbit $\left(\sigma^{\mathrm{SO}}\right)$ shieldings: ${ }^{7 \mathrm{~b}, 20}$

$\sigma=\sigma^{D}+\sigma^{P}+\sigma^{S O}$

$\delta=\sigma_{\text {reference }}-\sigma$

The $\sigma^{\mathrm{P}}$ and $\sigma^{\mathrm{SO}}$ terms are those with the largest effect on $\delta$ for ${ }^{207} \mathrm{~Pb}$ NMR. The diamagnetic shielding $\sigma^{\mathrm{D}}$ results from core terms depending on the density of electrons at the nucleus (associated to the circulation of electrons in orbitals determined by the ground state wave function) that seldom vary across different lead(II) complexes, and therefore are cancelled out in the final expression of $\delta$. The spin-orbit contribution $\sigma^{\text {sO }}$ is significantly affected by changes in the atomic number of the elements directly bonded to the $\mathrm{Pb}$ atom, and is particularly important for elements with large spin-orbit constant $(\mathrm{Br}, \mathrm{I})$. Its value increases with atomic number, and it is likely to play a significant role in the chemical shift for 1-3 and 5. The paramagnetic term $\sigma^{P}$ is related to the movement of electrons between ground and excited states, with the main contribution coming from excitation from $\mathrm{S}_{0}$ to $\mathrm{S}_{1}$. Increasingly electronegative elements lower the level of the ground state $S_{0}$, resulting in a drop of $\sigma^{P}$. The outcome is a decrease of the overall isotropic shielding $\sigma$ and, as a consequence, shielding of the $\mathrm{Pb}$ nucleus and a more highfield chemical shift. ${ }^{7 b, 20}$ Overall, the trend of increased shielding seen upon descending group 14 in the series of complexes 1-3 and $\mathbf{5}$ is therefore likely to be set by both the changing contributions of $\sigma^{P}$ and $\sigma^{\text {so }}$. Further comments on this trend will require a detailed DFT analysis.

The dimeric geometry of $\mathbf{5}$ was a surprise, as we expected the compound would crystallise with a terminal fluoride ligand, as for the heavier analogues 1-3 and for [ $\left.\left\{\mathrm{BD}||^{\mathrm{DiPP}}\right\} \mathrm{PbF}\right] .^{2}$ It was also our general assumption that the $\left\{\mathrm{Carb}^{\mathrm{DiPP}}\right\}^{-}$ligand was more 

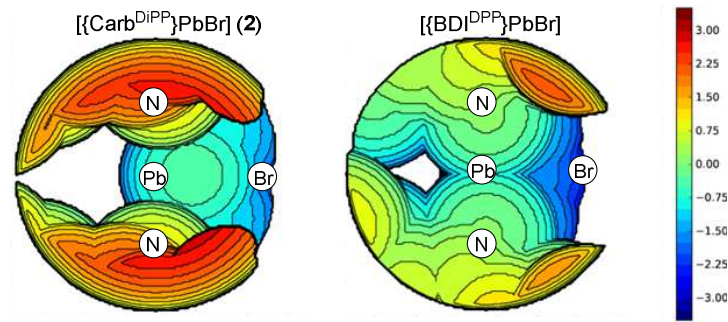

Fig. 4 Topographic steric map of the $\% \mathrm{~V}_{\text {bur }}$ bulk distribution, defined as the percent of the total volume of a sphere $(r=3.5 \AA)$ occupied by the ligand. Left: $\left\{\right.$ Carb $\left.^{\text {DipP }}\right\}$ ligand in 2. Right: $\left\{B D I^{D i P P}\right\}-$ ligand in $\left[\left\{B D I^{D i P P}\right\} P b B r\right] .{ }^{\text {6a }}$ Isocontour scheme, in $\AA$, displayed on the right. The maps are a $2 \mathrm{D}$ isocontour representation of the interaction surface $S(x, y)=z_{B}$, as defined in reference $21 d$. See $S \mid$ for details.

sterically cumbersome than $\left\{B D I^{D i P P}\right\}$, on account of its wider bite angle, as well as from the empirical evidence gathered from related barium chemistry. ${ }^{12}$ To better quantify the difference in steric profiles of the $\left\{\mathrm{Carb}^{\mathrm{DiPP}}\right\}^{-}$and $\left\{\mathrm{BDI}^{\mathrm{DiPP}}\right\}^{-}$ligands, buried volume calculations were carried out on a range of comparable $\mathrm{Pb}$ (II) halide complexes (Fig. 4), using the freeware Sambvca 2.1. ${ }^{21}$ The different percentages of buried volume $\left(\% \mathrm{~V}_{\text {bur }}\right)$ were calculated from the crystal structure for each of the halides $\left[\left\{\left.B D\right|^{D i p p}\right\} \mathrm{PbX}\right]^{6 \mathrm{a}}$ and 1-3 for $\mathrm{X}=\mathrm{I}, \mathrm{Br}, \mathrm{Cl}$; the fluorides were left out on account of the dimeric structure of $\mathbf{5}_{2}$. $\% \mathrm{~V}_{\mathrm{bur}}$ is a single value parameter used to access steric bulk as a percentage of the first coordination sphere (of radius $r$ ) around the central metal atom occupied by a ligand. ${ }^{21}$ The qualitative results give an indication about the relative steric profiles of the ligands and show that $\% \mathrm{~V}_{\text {bur }}$ for $\left\{B D I^{D i P P}\right\}^{-}$is substantially smaller than for the $\left\{\mathrm{Carb}^{\mathrm{DiPP}}\right\}^{-}$ligand, compare the values for $1\left(\% \mathrm{~V}_{\text {bur }}=54.5 \%\right)$, $2(55.0 \%), 3(54.9 \%)$ and for the corresponding [ $\left.\left.3 \mathrm{BDI}{ }^{\mathrm{DiPP}}\right\} \mathrm{PbX}\right]$ complexes ${ }^{6}$ where $\mathrm{X}=\mathrm{I}(47.4 \%), \mathrm{Br}(48.5 \%)$ and $\mathrm{Cl}(49.0 \%)$. The $\left\{\text { Carb }^{\text {DiPP }}\right\}^{-}$ligand hence lends itself better to a spatially tight control of the coordination sphere around a metallic centre.

The $\mathrm{Pb}(\mathrm{II})$-halides $\mathbf{1 - 3}$ and $\mathbf{5}$ constitute valuable synthetic precursors. For instance, the reaction of $\mathbf{3}$ with $\left[\mathrm{LiCH}\left(\mathrm{SiMe}_{3}\right)_{2}\right]$ afforded the lead(II)-alkyl [ $\left.\left\{\mathrm{Carb}^{\text {DipP }}\right\} \mathrm{PbCH}\left(\mathrm{SiMe}_{3}\right)_{2}\right](6)$ in a nonoptimised $44 \%$ yield. Complex 6 is an orange solid which crystallised from a petroleum ether solution spiked with toluene. Its identity was established by XRD analysis (Fig. S32), and purity was confirmed by NMR. Its four-coordinate molecular structure resembles closely that of 4 . The ${ }^{207} \mathrm{~Pb}$ NMR spectrum of 6 exhibits a resonance at $\delta_{\mathrm{pb}} 2950 \mathrm{ppm}\left(\Delta \mathrm{v}_{1 / 2}=651\right.$ $\mathrm{Hz}$ ), i.e. towards the highfield limit of chemical shifts for heteroleptic lead(II)-alkyl complexes. ${ }^{7}$ The diagnostic resonance for $\mathrm{CH}\left(\mathrm{SiMe}_{3}\right)_{2}$ in the ${ }^{1} \mathrm{H}$ NMR spectrum appears at $-0.97 \mathrm{ppm}$.

In summary, the bis(imino)carbazolate $\left\{\mathrm{Carb}^{\mathrm{DiPP}}\right\}^{-}$is a new addition to the set of tools available to organometallic and coordination synthetic chemists for the preparation of molecular lead(II) compounds. It is a versatile ligand that allows for the preparation of stable heteroleptic lead(II) halides, alkyls and amides, and as such it is a useful complement to the ever popular $\left\{B D I^{D i P P}\right\}-\beta$-diketiminate. In line with our initial insight in the chemistry of s-block metals, ${ }^{12}$ the results disclosed herein suggest that $\left\{\text { Carb }^{\text {DipP }}\right\}^{-}$affords improved steric control over the coordination sphere around large metal ions. The synthesis and characterisation, including by ${ }^{207} \mathrm{~Pb} N M R$ in solution, of a stable
$\mathrm{Pb}$ (II) fluoride, has been achieved, and hence a full comparative set of ${ }^{207} \mathrm{~Pb}$ NMR data for $\mathrm{Pb}$ (II) halides is available for the first time. We will next endeavour to capitalise on these spectroscopic data with a DFT analysis of the observed chemical shifts and deconvolution of the constitutive shielding constants.

The authors thank the Agence Nationale de la Recherche (ANR-17-CE07-0017-01 and ANR-11-LABX-0029) for support.

\section{Notes and references}

1 P. J. Davidson and M. F. Lappert, J. Chem. Soc., Chem. Commun., 1973, 317.

2 A. Jana, S. Pillai Sarish, H. W. Roesky, D. Leusser, I. Objartel and D. Stalke. Chem. Commun., 2011, 47, 5434.

3 J. Schneider, C. P. Sindlinger, K. Eichele, H. Schubert, and L. Wesemann, J. Am. Chem. Soc., 2017, 139, 6542.

4 A. Hinz, Chem. Eur. J., 2019, 25, 3267.

5 (a) A. Stasch, C. M. Forsyth, C. Jones and P. C. Junk, New J. Chem., 2008, 32, 829; (b) C. Jones, S. J. Bonyhady, N. Holzmann, G. Frenking and A. Stasch, Inorg. Chem., 2011, 50, 12315.

6 (a) M. Chen, J. R. Fulton, P. B. Hitchcock, N. C. Johnstone, M. F. Lappert and A. V. Protchenko, Dalton Trans., 2007, 2770; (b) S. Yao, S. Block, M. Brym and M. Driess, Chem. Commun., 2007, 3844

7 (a) A. Jana, S. P. Sarish, H. W. Roesky, C. Schulzke, A. Doring and M. John, Organometallics, 2009, 28, 2563; (b) M. J. Taylor, E. J. Coakley, M. P. Coles, H. Cox and J. R. Fulton, Organometallics, 2015, 34, 2515.

8 E. C. Y. Tam, N. A. Maynard, D. C. Apperley, J. D. Smith, M. P. Coles and J. R. Fulton, Inorg. Chem., 2012, 51, 9403.

9 E. C. Y. Tam, D. C. Apperley, J. D. Smith, M. P. Coles and J. R. Fulton, Inorg. Chem., 2017, 56, 14831.

10 E. C. Y. Tam, N. C. Johnstone, L. Ferro, P. B. Hitchcock and J. R. Fulton, Inorg. Chem., 2009, 48, 8971.

11 A. Jana, H. W. Roesky, C. Schulzke, P. P. Samuel and A. Döring, Inorg. Chem., 2010, 49, 5554.

12 P. M. Chapple, S. Kahlal, J. Cartron, T. Roisnel, V. Dorcet, M. Cordier, J.-Y. Saillard, J.-F. Carpentier and Y. Sarazin, Angew. Chem. Int. Ed., 2020, 59, 9120.

13 A. F. Kapustinskii, Q. Rev. Chem. Soc., 1956, 10, 283.

14 M. Born and J. Mayer, Z. Physik, 1932, 75, 1.

15 The lattice energy in $\mathrm{PbX}_{2}$ decreases with halide size. Other Kapustinskii and Born-Mayer energies (in $\mathrm{kJ} \mathrm{mol}^{-1}$ ): $\mathrm{PbCl}_{2}$, 2149/2061; $\mathrm{PbBr}_{2}, 2059 / 1975 ; \mathrm{Pbl}_{2}, 1930 / 1851$.

16 B. Wrackmeyer, Annu. Rep. NMR Spectrosc., 2002, 47, 1.

17 C. Bellini, J.-F. Carpentier, V. Dorcet, A. Silvestru and Y. Sarazin, Main Group Met. Chem., 2017, 40, 73.

18 E. C. Y. Tam, M. P. Coles, J. D. Smith and J. R. Fulton, Polyhedron, 2015, 85, 284.

19 A. Hinz, Chem. Eur. J., 2019, 25, 7843.

20 (a) A. Rodriguez-Fortea, P. Alemany and T. Ziegler, J. Phys. Chem. A, 1999, 103, 8288; (b) T. Müller, J. Organomet. Chem., 2003, 686, 251; (c) B. D. Rekken, T. M. Brown, M. M. Olmstead, J. C. Fettinger and P. P. Power, Inorg. Chem., 2013, 52, 3054.

21 (a) L. Falivene, R. Credendino, A. Poater, A. Petta, L. Serra, R. Oliva, V. Scarano and L. Cavallo, Organometallics, 2016, 35, 2286; (b) L. Falivene, Z. Cao, A. Petta, L. Serra, A. Poater, R. Oliva, V. Scarano and L. Cavallo, Nat. Chem., 2019, 11, 872; (c) SambVca 2.1: www.molnac.unisa.it/OMtools/sambvca2.1; (d) A. Poater, F. Ragone, R. Mariz, R. Dorta and L. Cavallo, Chem. Eur. J., 2010, 16, 14348. 